\title{
AUTORITARISMO E DEMOCRACIA NOS FILMES "JÂNIO A 24 QUADROS" (1981, DE LUÍS ALBERTO PEREIRA) E "JANGO" (1984, DE SILVIO TENDLER)
}

\section{AUTHORITARIANISM AND DEMOCRAÇY IN THE MOTION PICTURES "JÂNIO A 24 QUADROS" (1981, DIRECTED BY LUÍS ALBERTO PEREIRA) AND “JANGO" (1984, DIRECTED BY SILVIO TENDLER)}

Rodrigo Francisco Dias ${ }^{1}$

Recebido em: 24 de agosto de 2020 Aprovado em: 28 de outubro de 2020

RESUMO: Este artigo trata de como os temas do autoritarismo e da democracia são abordados nos filmes Jânio a 24 Quadros (1981, de Luís Alberto Pereira) e Jango (1984, de Silvio Tendler), dois documentários produzidos durante o processo de redemocratização do Brasil. Por meio da análise dos aspectos formais/estéticos dos dois filmes, pretendemos estabelecer um diálogo entre Cinema Documentário e História do Brasil.

Palavras-chave: Autoritarismo; Democracia; Cinema Documentário; História do Brasil.
ABSTRACT: This article deals with how the themes of authoritarianism and democracy are addressed in the films Jânio a 24 Quadros (1981, directed by Luís Alberto Pereira) and Jango (1984, directed by Silvio Tendler), two documentaries produced during the process of redemocratization in Brazil. Through the analysis of the formal/ aesthetic aspects of the two films, we intend to establish a dialogue between Documentary Cinema and History of Brazil.

Keywords: Authoritarianism; Democracy; Documentary Cinema; History of Brazil. 
Há 56 anos, as FA [Forças Armadas] intervieram na política nacional para enfrentar a desordem, subversão e corrupção que abalavam as instituições e assustavam a população. Com a eleição do General Castello Branco, iniciaram-se as reformas que desenvolveram o Brasil.

(Hamilton Mourão)

De 89 para cá foram sete eleições presidenciais. Chegou a hora de lembrar quais eram as promessas, as mentiras e as campanhas que nos trouxeram até aqui.

(Filipe Valerim)

O conteúdo das duas epígrafes deste texto é representativo de como a recente História Política brasileira tem sido interpretada por determinados setores de nossa sociedade. Na mensagem publicada na rede social Twitter no dia 31 de março de 2020 por Hamilton Mourão, general e atual vice-presidente da República Federativa do Brasil, percebe-se que o Golpe de 1964 é visto como um movimento que não apenas se contrapôs à "desordem", à "subversão" e à "corrupção" que, de acordo com o militar e político, marcavam a realidade brasileira do início dos anos 1960, mas também permitiu, segundo Mourão, a realização de "reformas que desenvolveram o Brasil" durante o período em que o país foi governado por presidentes militares entre 1964 e 1985. A imagem da Ditadura no Brasil, tal como elaborada por Mourão, portanto, é bastante positiva, algo que também acontece com frequência quando o próprio presidente da República, Jair Bolsonaro, fala publicamente a respeito do Golpe de 1964 e da Ditadura. ${ }^{2}$

Já na fala de Filipe Valerim, extraída do primeiro episódio de $\mathbf{O}$ Teatro das Tesouras, uma série de pequenos documentários produzidos pela Brasil Paralelo ${ }^{3}$ - a produtora de filmes da qual Valerim é um dos proprietários -, as eleições realizadas no âmbito da democracia representativa construída no Brasil ao longo das últimas décadas aparecem como eventos marcados por "promessas" e "mentiras". A fala de Valerim resume bem o modo como a série $\mathbf{O}$ Teatro das Tesouras (lançada em 2018, não por acaso um ano eleitoral, diga-se de passagem) descreve a democracia brasileira surgida após o fim da Ditadura Militar: um sistema político ineficaz e que não garante a real participação política do povo, uma vez que, de acordo com o ponto de vista da referida série, as eleições são sempre controladas por determinados grupos políticos. Como se vê, a imagem do atual Estado democrático de direito no Brasil, tal como elaborada por Valerim, é bastante negativa.

Analisadas em conjunto, as falas de Mourão e Valerim nos permitem identificar em determinados segmentos de nossa sociedade a existência de uma interpretação histórica segundo a qual o período da Ditadura não foi algo tão ruim e a atual democracia não é necessariamente algo tão bom. Uma interpretação deste tipo certamente tem terreno fértil em uma sociedade tão complexa e historicamente marcada pelo autoritarismo como é a sociedade brasileira. ${ }^{4}$ Ademais, as falas de Mourão

2 O presidente Bolsonaro tem, aliás, um longo e polêmico histórico de falas favoráveis ao Golpe de 1964 e à Ditadura que vigorou no Brasil entre 1964 e 1985 (Cf. DIAS, S. 2019).

3 A produtora Brasil Paralelo tem se dedicado, nos últimos anos, à produção de vários documentários a respeito dos mais diversos períodos da História do Brasil. Como bem observou Diego Martins Dória Paulo, em texto publicado no Le Monde Diplomatique Brasil, o conteúdo dos filmes produzidos pela Brasil Paralelo se caracteriza por seu tom conservador, em que chama a atenção a presença de "uma visão revisionista de 1964" (PAULO, 2020).

4 Sobre as diferentes manifestações do autoritarismo ao longo da História do Brasil, ver o recente trabalho de Lilia Moritz Schwarcz (2019). 
e Valerim - e, no caso deste último, há que se levar em conta também o conteúdo dos filmes da sua já citada produtora, a Brasil Paralelo - coadunam-se com interpretações de viés revisionista que têm sido cada vez mais comuns nas últimas décadas. Ora, tomando como base os apontamentos de Maria Helena Rolim Capelato, temos que

O revisionismo histórico implica reinterpretar a história. As revisões podem tanto contribuir para modificações das análises sobre um determinado fenômeno ou fato histórico como podem servir para justificar interesses de natureza diversa. No primeiro caso, trata-se de um procedimento acadêmico plenamente aceito que contribui para o avanço do conhecimento do passado; já no segundo, a revisão decorre de intenções alheias ao campo da história, porque não leva em conta os padrões acadêmicos que orientam os procedimentos da investigação histórica e do método histórico e, dependendo dos interesses em pauta, manipula dados/fatos e apresenta interpretação deturpada do passado. (CAPELATO, 2016, p. 22)

Embora a produção historiográfica profissional seja pautada pelos constantes exercícios de revisão orientados por mudanças nos pressupostos teórico-metodológicos e pelo contato com novos documentos e objetos, é preciso lembrar que os historiadores não possuem o monopólio da escrita da História e que outros atores sociais também elaboram narrativas e interpretações a respeito do passado muitas vezes com o intuito de "justificar interesses de natureza diversa". Nesse sentido, as interpretações de caráter revisionista que ignoram os aspectos negativos da Ditadura e os aspectos positivos da democracia fazem um "uso político"5 muito específico do passado que, em nossa avaliação, contribui para reforçar projetos autoritários de sociedade.

Tendo em vista tal cenário, cabe-nos a pergunta: como os estudos acerca das relações entre Cinema Documentário e História do Brasil podem contribuir para a construção de uma cultura política que não só rejeite veementemente o autoritarismo, mas que também fortaleça as bases do Estado democrático de direito em nosso país? Acreditamos que trazer à tona as interpretações históricas realizadas por dois documentários brasileiros produzidos na primeira metade dos anos 1980 - Jânio a 24 Quadros (1981, de Luís Alberto Pereira) e Jango (1984, de Silvio Tendler) - pode ser particularmente útil para a elaboração de uma resposta a tal questão.

\section{0 valor da democracia nos filmes "Jânio a 24 Quadros" e "Jango"}

Tanto Jânio a 24 Quadros quanto Jango apresentam uma espécie de balanço da História Política do Brasil da década de 1950 até o início dos anos 1980. Deste modo, os dois filmes foram produzidos e lançados durante os anos finais da Ditadura e, a partir de tal conjuntura, apresentaram ao público da época duas interpretações acerca de diversos acontecimentos históricos ocorridos nas décadas anteriores. Ambos os filmes podem ser inseridos no contexto da chamada "cultura de oposição" à Ditadura Militar que vigorou no Brasil entre 1964 e 1985, sendo que, em cada uma das duas narrativas fílmicas, merece destaque o esforço empreendido pelos cineastas no sentido de ressaltar o valor da democracia diante do cenário imposto por um regime autoritário.

5 Para uma análise mais aprofundada acerca dos "usos políticos” do passado, ver a obra publicada por François Hartog e Jacques Revel (2001). 
Nos dois documentários, tal exercício é feito por meio de imagens e sons que tratam do contexto histórico anterior ao Golpe de 1964, sobretudo o período da década de 1950, que é retratado nos filmes como os "anos dourados". Aqui, os dois documentários vão ao encontro da "memória hegemônica" sobre os anos 1950 no Brasil que, de acordo com Heloisa Helena Pacheco Cardoso, tem sido difundida por diversos meios de comunicação:

Reportagens em televisões, ou em jornais e revistas, investem na recuperação de memórias sobre os anos 50, centrando-as no personagem JK e na cidade de Brasília, símbolos das mudanças que modernizaram o país. A imagem do presidente Juscelino vem sendo reelaborada na sua positividade desde os anos de 1980. Naquele momento, quando os caminhos da ditadura pós-1964 indicavam o seu fim, trazer, para o social, temas como democracia, modernidade, otimismo, humanidade, cumpria a função de reforçar as expectativas da sociedade na possibilidade de um Brasil novo. Esse investimento em uma dada memória, trazendo, para o presente, elementos dos anos 50, continua nas décadas seguintes. Anualmente, o nascimento de JK, a sua posse como presidente, a morte, a inauguração de Brasília são momentos onde as marcas de um passado se tornam oportunidade para reconstruir, a partir delas, a história do Brasil que se quer oficializar. (CARDOSO, 2007, p. 171)

Em Jânio a 24 Quadros, a trilha sonora é um dos recursos utilizados para a composição de um quadro geral bastante positivo em relação aos anos 1950. Enquanto a tela exibe diversas imagens de arquivo que retratam acontecimentos do período, canções como Biquíni de Bolinha Amarelinha, Cachito mio, Fanzoca do Rádio, A Taça do Mundo é Nossa, Rio, 40 Graus, Chega de Saudade, Diana e os jingles políticos de algumas lideranças políticas da época embalam as cenas do filme que mostram a década de 1950 como um período de otimismo e democracia. Tal representação dos anos 1950 está relacionada ao fato de o filme apresentar a figura de Juscelino Kubitschek - um dos principais personagens do cenário político brasileiro daquele momento - como a de um bom líder político. A própria narração em off feita no filme pela voz over de Neide Duarte descreve o governo JK como "um governo de estabilidade política, de abertura ao capital estrangeiro, de fatos marcantes na cultura, de várias agitações populares, mas também de muita euforia". ${ }^{6}$

Essa "euforia" do período é ressaltada justamente pelas canções citadas acima e que compõem a trilha sonora de Jânio a 24 Quadros durante as cenas do filme que tratam dos anos 1950 e que mostram o povo brincando o carnaval de rua, a seleção brasileira de futebol masculino durante a vitoriosa campanha na Copa do Mundo de 1958, mulheres desfilando em um concurso de beleza, pessoas na região da praia de Copacabana (no Rio de Janeiro), revistas da época falando sobre rock e cinema, a inauguração da cidade de Brasília, alguns dos personagens da política nacional do período (Jânio Quadros, Ademar de Barros, Marechal Teixeira Lott, João Goulart, Milton Soares Campos, além do já citado Juscelino Kubitschek) e a chegada de Jânio Quadros à Presidência da República em 1961. Mesmo quando o documentário de Luís Alberto Pereira exibe cenas da Revolta das Barcas ocorrida em Niterói no ano de 1959, que mostram um quebra-quebra nas ruas com pessoas colocando fogo em vários objetos e destruindo um bonde, o filme não deixa de lado o tom "eufórico" que é embalado pela trilha sonora.

6 Trecho transcrito diretamente do filme Jânio a 24 Quadros [Transcrição nossa. Não Publicado]. Todos os trechos citados são retirados do referido filme, salvo quando vier indicada por referência bibliográfica específica. O mesmo se aplica aos trechos transcritos diretamente do filme Jango. 
Tal aspecto do filme chamou a atenção de alguns dos comentadores do mesmo quando a obra foi objeto de análise em alguns textos publicados na imprensa à época de seu lançamento. 0 repórter político Villas-Bôas Corrêa, por exemplo, escreveu no Jornal do Brasil que a abordagem do período anterior a 1964 presente em Jânio a 24 Quadros caracteriza-se por assumir um tom vivo, brilhante e de "interesse absorvente", em contraste com a "monotonia" com a qual o filme, segundo Corrêa, abordou o período da Ditadura no Brasil, período este descrito por Corrêa como o de uma "política sem povo" (Cf. CORRÊA, 1982, p. 1). Uma opinião similar a essa foi expressa por Rogério Bitarelli que, no dia 04 de agosto de 1982, publicou o seguinte no Jornal do Brasil:

O Brasil kitsch [mostrado em imagens em preto e branco], que descobre os caprichos consumistas da industrialização, é melhor e convence mais do que as rápidas inserções a cores como a de um personagem fazendo comentários enquanto toma banho de chuveiro; como a paródia à guerrilha urbana quando Tio Sam é sequestrado; como na reprodução da solenidade de condecoração de Che Guevara por Jânio, tendo a paisagem de Brasília ao fundo. As imagens antigas em preto e branco de um Brasil anterior ao toque de clarim e à TV em cores (mas ouvindo os tambores distantes do rock'n' roll) vistas hoje não parecem apenas momentos históricos documentados. Há também algo de ficcional: a ficção política dos últimos 35 anos de um país imaginário, [...] O ritmo de marchinha de carnaval da primeira parte do filme é interrompido após as imagens do movimento militar de 64. E quando Castelo Branco chega ao Planalto, investido na Presidência, a música já não é tão animada. Adquire um tom solene, de certa forma sombrio. (BITARELLI, 1982, p. 7)

Como se vê, tanto Villas-Bôas Corrêa quanto Rogério Bitarelli apontaram para o fato de que, no filme Jânio a 24 Quadros, enquanto o período democrático anterior a 1964 é mostrado como um período animado e eufórico, o período autoritário posterior a 1964 é mostrado como um período monótono e sombrio.

Embora tal observação feita pelos dois comentaristas tenha o mérito de colocar em evidência o tom crítico assumido pelo filme de Luís Alberto Pereira em relação ao autoritarismo, uma análise um pouco mais aprofundada de Jânio a $\mathbf{2 4}$ Quadros mostra que, apesar de o filme mostrar-se favorável ao Estado democrático de direito, a narrativa construída pelo documentário vai além de uma dicotomia simplista entre democracia e autoritarismo. O filme de Luís Alberto Pereira adota o deboche como ferramenta para a crítica política, deboche esse que, no documentário, é como que uma arma disparando para os mais diferentes lados, tal como bem observou Paulo Moreira Leite em matéria publicada na revista Veja:

Pereira submete o conjunto das forças políticas do país ao fogo de um irresistível deboche. Do governo à oposição, da luta armada do final dos anos 60 ao renascimento dos movimentos populares, ninguém consegue escapar, nem mesmo Lula, presidente do PT, tratado com simpatia e ironia. (LEITE, 1982, p. 125)

Embora a postura assumida pelo filme Jânio a 24 Quadros seja, de modo geral, favorável ao Estado democrático de direito, isso não quer dizer que o período democrático vivenciado pelo Brasil entre os anos 1950 e o início dos anos 1960 seja imune ao olhar crítico lançado pelo cineasta Luís Alberto Pereira. Vejamos, por exemplo, o trecho do filme que trata da eleição de Jânio Quadros para o cargo de governador do estado de São Paulo em 1954, durante o qual a narração em off afirma 
o seguinte:

[...] o homem da vassoura teria seu prestígio político consolidado na eleição de 54 para o Governo do Estado de São Paulo. Percorrendo todo o interior, espalhou vassourinhas, comeu sanduíches de mortadela, fez comícios mirabolantes com sua famosa oratória, mas não apresentava nenhum plano de governo, somente "Trabalho e Honestidade". Com esse lema, Jânio disputava a eleição. Mas Ademar de Barros era o grande candidato. Muito querido pelo povo, Ademar havia fundado o seu próprio partido, o PSP, e tinha nas mãos o controle político de todo o estado. No entanto, Ademar tinha um ponto fraco, que Jânio soube explorar na sua campanha: era a fama do político corrupto. Todo mundo falava da famosa "caixinha do Ademar" e do seu lema, "Roubo, mas faço". A campanha estava no auge. O suicídio do presidente Getúlio Vargas viria a colocar mais lenha na fogueira. Cada candidato tentava aproveitar o impacto emocional do momento para ganhar as simpatias populares. PTB, PSD, UDN, PDC, PTN, PSP, PSB, PRP, PL, PR, PST, PRT. O Partido Comunista continuava na ilegalidade. Jânio havia sido expulso do PDC, após desentendimentos com o então vereador Franco Montoro. Apurados os votos, uma diferença de dezoito mil, sobre Ademar, fez de Jânio o governador de São Paulo.

O fato de um candidato não apresentar nenhum plano de governo, mas apenas recorrer a comícios mirabolantes e a um vago discurso de "Trabalho e Honestidade" como estratégias de marketing político mostra as fragilidades da democracia representativa. Ademais, é preciso dizer que o trecho da narração na qual são citadas doze siglas partidárias - além do nome do Partido Comunista - é marcado por um tom elogioso-injurioso, ${ }^{7}$ pois, ao mesmo tempo em que se aponta para a grande variedade de partidos políticos existentes naquele contexto histórico, também rebaixa o valor de todos eles, afinal, se vários partidos políticos existem, qual é o valor real de cada um deles? Não por acaso, neste trecho do filme, a narração cita as siglas partidárias de maneira rápida e confusa.

Se em Jânio a 24 Quadros a democracia, embora possua um valor positivo, também apresenta alguns pontos frágeis, o documentário Jango, por sua vez, levanta a bandeira do Estado democrático de direito contra o autoritarismo da Ditadura Militar. O filme de Silvio Tendler também aborda a década de 1950 colocando em destaque alguns fatos que foram citados em Jânio a 24 Quadros, como a construção de Brasília durante o governo de Juscelino Kubitschek e a atuação de políticos como Jânio Quadros, João Goulart, Marechal Teixeira Lott e outros. Todavia, embora os dois filmes tenham alguns pontos em comum no que tange à elaboração da imagem dos anos 1950 como os "anos dourados", há algumas diferenças que devem ser observadas. No filme Jânio a 24 Quadros são muitas as referências à vida cultural do período (rádio, televisão, futebol, cinema, música), mas em Jango tais referências não aparecem com o mesmo destaque, pois no filme de Silvio Tendler o que é colocado em primeiro plano são aos acontecimentos da História Política do período, acontecimentos estes que são mostrados por meio de uma grande quantidade de imagens de arquivo. Em Jango, a narração em off feita pela voz do ator José Wilker até menciona o Cinema Novo e a Bossa Nova, por exemplo, mas o documentário não apresenta muitas imagens de arquivo sobre tais assuntos e, além disso, a própria trilha sonora possui uma quantidade menor de músicas

7 Tal tom elogioso-injurioso é característico do exercício de "enumeração", tal como observado por Mikhail Bakhtin quando de sua análise sobre a obra de François Rabelais e sobre as falas ouvidas nas praças públicas da Idade Média e do período do Renascimento. Segundo Bakhtin, a enumeração (o exercício de se listar vários objetos de uma mesma categoria) quando feita no sentido da hipérbole assume um caráter elogioso-injurioso ao apontar, a um só tempo, para a abundância e para o baixo valor dos objetos enumerados (Cf. BAKHTIN, 1987, p. 152 et seq.). 
do que aquela existente em Jânio a 24 Quadros.

Nesta perspectiva, o filme de Silvio Tendler constrói uma imagem positiva dos anos 1950 e do presidente Juscelino Kubitschek, porém, faz isso assumindo um tom mais "sério" se comparado ao filme de Luís Alberto Pereira, não possuindo o mesmo caráter "eufórico" do filme Jânio a 24 Quadros. De qualquer forma, vale citar o trecho da narração em off que, em Jango, faz um comentário bastante elogioso ao governo de JK: "Os cinco anos de JK sacudiram o Brasil. A modernização contagiou o país com a epidemia do novo. Bossa Nova, Cinema Novo, nova capital. Sua arquitetura arrojada tornou-se a moldura futurista de um país que exibia antigos contrastes. JK partiu seguro de que voltaria". No filme Jango, o balanço do período em que o Brasil foi governado por Kubitschek, portanto, é bastante favorável a JK, cujo governo é descrito como sendo de caráter moderno. Aqui, Tendler seguiu a mesma linha que já havia sido traçada em seu documentário Os Anos JK, que havia sido lançado em 1980, pois, de acordo com Amir Labaki, o filme Os Anos JK também apresentou "um balanço positivo do mais bem-sucedido governo democrático do período 1945-1964" (LABAKI, 2018).

Além da interpretação histórica favorável a JK, também há em Jango a construção de uma imagem bastante positiva do presidente João Goulart. A figura de "Jango" - como Goulart era conhecido -, aliás, é o personagem por meio do qual o cineasta Silvio Tendler tecerá no filme Jango as suas críticas ao Golpe de 1964 e à Ditadura que se instaurou no Brasil em seguida. A respeito disso, o próprio cineasta afirmou o seguinte em uma matéria publicada no Jornal do Brasil em 15 de fevereiro de 1984, depois de o seu filme ter sido inicialmente barrado pela censura:

Jango foi o único Presidente brasileiro a morrer no exílio. Por coincidência, foi também o único a mexer na estrutura social do país. Nem Getúlio, do qual Jango foi um descendente político, tentou modificar essa estrutura. Jango pagou o preço por essa tentativa, e de uma certa maneira, quando quero resgatar a sua figura, também estou pagando. Esse veto para participar do Festival [de Gramado-RS] reacende a censura política. Obviamente, a Censura não gostou, e algumas pessoas querem julgar o que é bom para o país. A causa, a meu ver, é simples: querem apagar a história de Jango da História do Brasil. Têm medo da figura de Jango, o que significa medo da história que construíram. [...] Sem dúvida [Jango] é um filme simpático a ele [à figura de João Goulart]. E quanto mais conheço Jango, mais simpatia tenho. [...] Quando um país quer superar suas chagas, o melhor processo é expô-las, e não abafá-las, escondendo feridas vivas e gangrenas. Quando Jango foi deposto eu tinha 14 anos, e um dos motivos alegados foi o de que queria dar um golpe de República sindicalista. Deram um golpe para evitar essa ditadura, e eu, que tenho 33 anos, nunca votei para Presidente. Acho que está na hora. (SCHILD, 1984, p. 1)

O fato de Tendler assumir claramente uma posição política no documentário Jango foi descrito por Villas-Bôas Corrêa nas páginas do Jornal do Brasil não como "um defeito", mas sim como "uma marca" do filme. Segundo Corrêa, a parcialidade do filme Jango era visível na "má vontade com o outro lado" como, por exemplo, na "seleção de trechos caricaturais do depoimento desconchavado do General Andrada Muricy" (CORRÊA, 1984, p. 1). A construção simultânea de uma imagem positiva de João Goulart e de uma imagem negativa do Golpe de 1964 e da Ditadura não foi, diga-se de passagem, uma exclusividade do filme Jango durante o contexto da abertura política em andamento no Brasil em meados dos anos 1980, época em que o documentário de Silvio Tendler foi lançado. Ao analisar uma série de materiais publicados na imprensa da época, a pesquisadora Flávia 
Biroli constatou que, no ano de 1984, predominou na grande imprensa brasileira uma caracterização positiva de João Goulart, ao mesmo tempo em que também foi frequente uma caracterização negativa do Golpe de 1964, de modo que, nas palavras da pesquisadora, aos poucos "Goulart vai sendo caracterizado como um 'outro' do golpe e da ditadura" (BIROLI, 2006, p. 12).

O tom da caracterização positiva do governo João Goulart pode ser percebido em uma cena do filme Jango na qual a tela exibe um trem em movimento transportando uma grande quantidade de pessoas que, pelo modo como estão vestidas, provavelmente são trabalhadores rurais, enquanto a narração em off afirma o seguinte:

Democratização do uso da terra. Voto do analfabeto. Disciplina dos aluguéis. Bases justas para o salário mínimo. Estes pontos fixavam as regras de um programa de governo capaz de estabelecer maior harmonia social. Jango propunha o fim da fome e da miséria num país onde a justiça sempre foi o lado obscuro da democracia. A situação do Nordeste recebeu atenção particular do governo. Sobre os planos do presidente recairiam em 64 as mesmas acusações feitas a ele, ministro do Trabalho em 54: "fomentador de greves", "articulador da luta de classes", "inimigo do capitalismo". Os trabalhadores rurais, mobilizados pelo processo de transformação social, eram despertados contra a secular miséria do campo. A perspectiva de pequenas mudanças num país de grandes desigualdades reacendeu ilusões. Milhares de trabalhadores, sem-terra e sem trabalho, embarcaram neste trem de esperanças, saltando das páginas da literatura para o cenário político. Jango, com as reformas, fez o Brasil viver a sua utopia.

O trecho da narração presente no filme Jango citado acima é exemplar do tom geral assumido pelo filme quando da abordagem do papel desempenhado por João Goulart durante a década de 1960. Do ponto de vista do documentário de Silvio Tendler, Goulart foi um figura comprometida com a democracia e que tentou enfrentar as históricas desigualdades sociais existentes no Brasil ao levantar a bandeira das "reformas de base" - ainda que tal bandeira tenha sido uma utopia, de acordo com a narração -, tendo por isso incomodado setores conservadores da sociedade brasileira e, consequentemente, terminando por ser vítima de um golpe de Estado que o tirou da Presidência da República em 1964.

O Golpe de 1964 e a Ditadura são alvo de fortes críticas no documentário Jango, algo que também acontece no filme Jânio a 24 Quadros, como veremos a seguir.

\section{Dois filmes contra 0 autoritarismo}

A narrativa de Jânio a 24 Quadros prepara o terreno para tratar do Golpe de 1964 e da Ditadura no Brasil por meio de uma sequência que aborda a renúncia de Jânio Quadros, em 1961, episódio que instaurou uma crise política no país em função da oposição de alguns setores da sociedade brasileira, sobretudo no interior das Forças Armadas, à posse do vice, João Goulart, no cargo máximo do poder Executivo nacional. Em poucos minutos, o filme narra a breve experiência parlamentarista no Brasil - saída encontrada à época por parte dos opositores de Goulart para tentar impedir que "Jango" governasse o país com plenos poderes - , a retomada do presidencialismo e a mobilização popular em torno das "reformas de base" propostas por João Goulart. Neste momento, 


\section{DOSSIÊ}

escuta-se na trilha sonora a canção Please Please Me, dos Beatles. A montagem alternada assume nesta sequência de Jânio a 24 Quadros um importante papel na narrativa: imagens de militares em movimento vão se alternando com as imagens do povo nas ruas. Sons de transmissões de rádio falando da mobilização das tropas no contexto do Golpe de 1964 abafam o som da canção dos Beatles e, de repente, ouve-se o famoso trecho da fala do então governador do estado da Guanabara, Carlos Lacerda, dirigida ao Almirante Aragão: "Almirante Aragão! Almirante Aragão! Assassino, monstruoso! Incestuoso miserável! Almirante Aragão, não se aproxime porque eu te mato com o meu revólver, canalha! Patife! Traidor!". Pouco depois, temos o conhecido trecho da fala do senador Auro de Moura Andrade: "Assim sendo, declaro vaga a Presidência da República! E nos termos do artigo 79 da Constituição, declaro presidente da República o presidente da Câmara dos Deputados, Ranieri Mazzilli". Diversos gritos são ouvidos na trilha sonora, enquanto a tela exibe diversas imagens de arquivo que remetem aos acontecimentos daqueles dias, como a realização da "Marcha da Vitória" - manifestação ocorrida no Rio de Janeiro em comemoração ao Golpe de 1964.

Para além do fato de esta sequência de Jânio a 24 Quadros possuir um tom bastante tenso, o que chama a atenção é que, do ponto de vista da narrativa elaborada por Luís Alberto Pereira, o Golpe de 1964 aparece como uma ruptura em relação ao Estado democrático de direito no Brasil. Não por acaso, os militares substituem o povo nas ruas neste momento do filme e, em seguida, um perturbador silêncio toma conta da trilha sonora enquanto são exibidas na tela imagens de alguns políticos do período, das quais merece destaque aquela que mostra Gregório Bezerra no chão e rodeado por militares. A crítica à violência praticada pelo Estado brasileiro durante a Ditadura também é feita por meio de uma metáfora visual: em outro momento do filme, vemos imagens de um céu carregado de negras nuvens enquanto o som de trovões se faz ouvir na trilha sonora, como se o tempo estivesse literalmente "ficando ruim" no céu do Brasil.

O autoritarismo e a violência da Ditadura são ainda mais explicitados quando a tela exibe imagens de jovens protestando nas ruas no final dos anos 1960. Em uma cena, vê-se um cartaz com o nome do estudante Edson Luís, que foi morto por policiais militares durante um confronto que ocorreu na região do restaurante universitário "Calabouço", no Rio de Janeiro, em março de 1968. Em outra sequência, ouve-se um áudio que anuncia um Ato Institucional baixado pela Ditadura, segundo o qual a sua finalidade era "preservar a revolução de março de 1964". Logo após esse áudio - uma clara referência ao conhecido Ato Institucional n 5, de 13 de dezembro de 1968 -, a tela mostra o Congresso Nacional de cabeça para baixo. O autoritarismo dos militares virava, portanto, a democracia brasileira de ponta-cabeça. Como que para corroborar essa ideia, o filme exibe também, em outra sequência, imagens de arquivo que mostram confrontos nas ruas entre os opositores do regime e os militares, nas quais se percebe uma grande correria, com pessoas gritando "Assassino! Covarde!" e jogando pedras contra as tropas do governo sob os sons de tiros e bombas.

As cenas de Jânio a 24 Quadros descritas acima são marcadas, de fato, por muita tensão. Todavia, apenas a análise dessas cenas não é suficiente para entendermos a complexidade da crítica feita pelo filme de Luís Alberto Pereira ao autoritarismo. Um aspecto fundamental do filme na elaboração de sua crítica ao Golpe de 1964 e à Ditadura é o tom irônico assumido pela narrativa em 
diversos momentos. ${ }^{8}$ Há uma cena em que a tela mostra uma espécie de Estátua da Liberdade desenhada em um pedaço de papelão apoiado em uma parede, onde está escrito "Estátua da Liberdade Brasil 68", sendo que a palavra "Liberdade" está entre aspas e o próprio desenho dessa "Estátua da Liberdade" é, na verdade, uma imagem de um militar fortemente armado.

A ironia do filme volta a aparecer na sequência que mostra a chegada do general Emílio Garrastazu Médici à Presidência da República, em 1969. Se na trilha sonora ouve-se um trecho do discurso de Médici, no qual o militar afirma que "Homem da lei, sinto que a plenitude do regime democrático é uma aspiração nacional. $\mathrm{E}$, para isso, creio necessário consolidar e dignificar o sistema representativo, baseado na pluralidade dos partidos e na garantia dos direitos fundamentais do homem", a imagem não perdoa: na tela, vê-se um homem no chão, machucado, sem camisa e gritando, tendo perto de si a perna de alguém que usa uma capa de couro - provavelmente é um militar que está perto do homem. Trata-se de uma breve encenação que faz clara referência aos episódios de tortura ocorridos nos porões da Ditadura. O homem que está no chão tem os cabelos e a barba grandes e, pelo que o filme mostra, ele não está tendo os seus "direitos fundamentais" respeitados, como prometera Médici em seu discurso. 0 tom geral dessa cena remete ao grotesco a câmera filma a boca aberta do homem ${ }^{9}$ - e a imagem do homem torturado desmente, com ironia, o discurso de Médici.

Há ainda uma sequência, ambientada no final dos anos 1970, na qual é mostrada uma televisão exibindo o Jornal Nacional e há um trecho de uma entrevista do General Dilermando Monteiro (Comandante do II Exército) afirmando que o Brasil vivia uma "fase tranquila" e sem "nenhum aspecto de golpe militar", mas que havia apenas problemas de ordem política que, segundo ele, seriam comuns em períodos eleitorais. A montagem de Jânio a $\mathbf{2 4}$ Quadros novamente trabalha no sentido de desmentir o que é falado: a tela exibe imagens de jornais impressos da época noticiando as tensões presentes na disputa eleitoral entre os generais João Batista Figueiredo e Euler Bentes Monteiro, candidatos à Presidência da República nas eleições indiretas de 1978. A ironia fica ainda mais evidente quando a tela mostra dois outdoors, um do lado do outro e filmados de maneira que o movimento de câmera vai do primeiro - o que mostra o suposto apoio dado pela comunidade de Santo Amaro ao presidente João Batista Figueiredo - ao segundo - o que faz uma propaganda da cachaça 51 (a propaganda do outdoor diz "Eleita pelo povo"). A ironia aqui está justamente no fato de que, apesar da fala de Dilermando Monteiro, segundo a qual não havia nenhum aspecto de golpe militar no Brasil, a população brasileira - o povo - da época só tinha a liberdade de escolher qual a marca de cachaça consumir, tendo em vista que as eleições presidenciais eram indiretas. Os tempos, portanto, não eram efetivamente democráticos, de acordo com o ponto de vista assumido pelo filme.

O próprio processo de abertura política iniciado no Brasil também é tratado com ironia no filme. Quando a tela exibe manchetes de jornais da época falando do fim do bipartidarismo e do restabelecimento do pluripartidarismo, em um contexto marcado por tensões políticas - recordemos

8 É preciso registrar que o uso da ironia e do humor (por vezes marcado pelo absurdo e pelo deboche) é um aspecto recorrente em diversos outros filmes dirigidos pelo cineasta Luís Alberto Pereira ao longo de sua trajetória no cinema nacional (Cf. DIAS, R., 2019, p. 103-106).

9 De acordo com Mikhail Bakhtin (1987, p. 269), a "bocarra aberta” é um dos sinais da vida grotesca do corpo. 
os atentados na sede da $O A B$ e no Riocentro, acontecimentos que também são mencionados nas manchetes de jornais exibidas na tela -, a trilha sonora é ironicamente composta pela música Mania de Você, cantada na voz de Rita Lee, que diz: "Meu bem, você me dá água na boca". Todavia, quando o espectador lê as manchetes de jornais, fica a sensação de que aquela conjuntura não era de dar "água na boca" em ninguém. Novamente, temos aqui o uso da ironia, que se vale nesta sequência da letra da canção.

A recorrente presença da ironia no filme de Luís Alberto Pereira está relacionada com o fato de que, em Jânio a $\mathbf{2 4}$ Quadros, o autoritarismo não é o único alvo das críticas, já que há cenas em que a narrativa trata com desconfiança dos vários atores e grupos políticos que se faziam presentes no contexto da lenta redemocratização em andamento no país quando da produção do filme, tais como os comunistas liderados por Luís Carlos Prestes, o movimento estudantil, a juventude do Partido Trabalhista Brasileiro e até mesmo Luiz Inácio Lula da Silva e o Partido dos Trabalhadores. De acordo com Hayden White, a ironia "tende a dissolver toda crença na possibilidade de ações políticas positivas" (WHITE, 2008, p. 52), e é exatamente isso o que se percebe em Jânio a 24 Quadros, já que o filme de Luís Alberto Pereira se mostra incapaz de indicar claramente um caminho a ser seguido pela sociedade brasileira naquele momento em que a obra foi lançada.

O final do filme é emblemático desse ponto de vista, uma vez que a narrativa termina de maneira aberta, sem apontar com segurança nenhum caminho a ser seguido pela população brasileira à época de seu lançamento. $O$ final do filme é composto por imagens de Brasília - a esplanada dos Ministérios, a Praça dos Três Poderes, o Congresso Nacional, o Memorial JK, o Palácio do Planalto, a Torre de TV. Na trilha sonora é possível ouvir os sons de um aparelho de rádio sendo sintonizado, há a sucessão de trechos musicais diversos e também o som de ondas radiofônicas. A metáfora sonora é: o Brasil ainda estava tentando "se sintonizar" no interior do contexto histórico da abertura política. O último plano do filme mostra a Torre de TV de Brasília, enquanto na trilha sonora ouve-se a canção Brasil Pandeiro, dos Novos Baianos, da qual o primeiro verso é cheio de significado: "Chegou a hora dessa gente bronzeada mostrar seu valor". O final do filme, portanto, tem o tom do final de uma comédia, pois, se levarmos em conta a reflexão proposta por Hayden White, a comédia geralmente termina com uma espécie de reconciliação, por vezes com um tom festivo, podendo apontar até mesmo para as possibilidades de que as coisas sejam diferentes no futuro (CF. WHITE, 2008, p. 24-25). Ora, é justamente isto o que vemos ao final do filme de Luís Alberto Pereira: um final no estilo de uma comédia, algo que combina, diga-se de passagem, com os diversos momentos do filme em que a ironia, e até mesmo o deboche, trata com humor certos personagens e episódios da recente História do nosso país. ${ }^{10}$

A abordagem a respeito do Golpe de 1964 e da Ditadura no filme Jango, de Silvio Tendler, é feita por meio de uma série de imagens de arquivo e de depoimentos que, somados a narração feita pelo ator José Wilker, tratam do contexto que levou ao Golpe, marcado pela crise iniciada com a renúncia de Jânio Quadros e pela conjuntura mais ampla da "luta ideológica" no âmbito da Guerra Fria, em que as "reformas de base" defendidas por João Goulart foram interpretadas por alguns 
setores da sociedade brasileira como sinais da presença de um suposto "perigo comunista" no Brasil. O tema das reformas ganha papel de destaque no documentário e a narrativa de Silvio Tendler posiciona os diferentes grupos políticos do período do seguinte modo: os grupos "de esquerda" aparecem como favoráveis às reformas de base, sendo de modo geral retratados no filme como grupos comprometidos com a democracia e com a justiça social, já os grupos "de direita" aparecem como inimigos das reformas de base, sendo de modo geral retratados no filme como grupos não só ignorantes, mas também intolerantes e violentos. ${ }^{11}$

No filme Jango, o uso da violência para impedir as reformas de base é, aliás, um dos principais aspectos que permitem no documentário a elaboração de uma crítica ao autoritarismo. Isso é perceptível mesmo antes de o filme tratar especificamente do período da Ditadura. Na sequência que mostra o líder comunista David Capistrano tentando falar em público, por exemplo, na qual ele está em um palanque na cidade de Caruaru, o seu discurso é interrompido por várias pessoas. As imagens e a trilha sonora revelam as vaias, os gritos, os objetos sendo jogados em direção ao palanque, barulhos de bombas explodindo e o início de um tumulto. A narração em off assim comenta tais cenas exibidas na tela: "O líder comunista David Capistrano, que seria tragado pela violência do Estado nos anos setenta, sofria a intolerância dos anos sessenta". A narrativa de Jango estabelece, portanto, uma ligação entre a violência da Ditadura e a violência de determinados grupos políticos antes mesmo do Golpe de 1964, ligação essa que é reforçada quando o filme trata da tentativa de atentado na Exposição Soviética ocorrida no Brasil, em 1962, atentado esse que, de acordo com a narração, foi planejado "nos porões do Governo da Guanabara", e do ataque à sede da UNE pelo Movimento Anticomunista (MAC).

O documentário Jango elabora deste modo um retrato do contexto que levou ao Golpe de 1964. No que diz respeito ao Golpe em si, este episódio é abordado por meio de imagens de arquivo em preto e branco que mostram tanques de guerra nas ruas do Rio de Janeiro e de Brasília, a sede da UNE sendo incendiada, manifestações nas ruas favoráveis ao Golpe, bem como políticos discutindo no Congresso. Assim como em Jânio a 24 Quadros, também temos em Jango o áudio do discurso do senador Auro de Moura Andrade que, naquele cenário conturbado e ainda com Goulart em território nacional, declarou vaga a Presidência da República - um discurso que é descrito pela voz over de José Wilker como um gesto de "solene desprezo pelo destino das instituições legais". Após a fala do senador, ouve-se também gritos de "Golpista! Golpista!". É um dos momentos mais tensos do documentário, e no qual o cineasta Silvio Tendler torna explícito o seu ponto de vista contrário aos atores sociais responsáveis pelo Golpe e pela posterior instauração de uma Ditadura no Brasil.

Cabe mencionar ainda que os agentes envolvidos na realização do Golpe de 1964 são descritos no filme não só como violentos, autoritários e inimigos da luta contra as desigualdades sociais, mas também como sujeitos que naquele momento agiram em sintonia com os interesses dos Estados Unidos da América. Ao registrar que, no quadro da Guerra Fria, os EUA apoiaram o Golpe de 1964 por meio da chamada "Operação Brother Sam", o documentário Jango elabora uma imagem bastante negativa dos agentes do Golpe, vistos como figuras mais comprometidas com os interesses de

$11 \mathrm{O}$ compromisso com as teses oriundas do campo político da "esquerda", sobretudo no que diz respeito à interpretação marxista a respeito do papel desempenhado pela "luta de classes" na História, é um traço comum em vários documentários que fazem parte da filmografia de Silvio Tendler (Cf. DIAS, R. 2019, p. 118-122). 
um outro país do que com a luta pela justiça social no Brasil.

O autoritarismo da Ditadura aparece em Jango em diversas cenas que são carregadas de tensão e de emoção. Algumas imagens de arquivo são acompanhadas da canção Coração de Estudante, de Milton Nascimento, e mostram ao espectador a dimensão da violência de Estado implantada a partir do Golpe de 1964: militares nas ruas reprimem os civis, pessoas correndo de um lado para o outro, confusão nas ruas, a prisão do líder comunista Gregório Bezerra. Merece destaque a sequência que trata do assassinato do estudante Edson Luís no Rio de Janeiro, em 1968, fato que gerou à época, como se sabe, uma série de manifestações nas ruas contra a Ditadura. A esse respeito, o documentário Jango exibe imagens de uma multidão nas ruas carregando o caixão de Edson Luís, com algumas pessoas com cartazes e faixas que dizem "Yankees mataram um brasileiro", "E. E. U. U. > Morte" (ou seja, Estados Unidos provocam a Morte), "O povo perde sangue", "Fora com militares", "Assassinos", "Vingança". As imagens de arquivo também revelam o apoio dado por artistas aos protestos contra a Ditadura, vemos Vinícius de Moraes e Tônia Carrero sendo entrevistados e posicionando-se favoravelmente aos protestos. A carga de emoção dessa sequência se deve não só às imagens, mas especialmente à trilha sonora, composta pela canção Menino, cantada na voz de Milton Nascimento.

Em outra sequência, temos novas imagens de pessoas protestando nas ruas e sendo vítimas da repressão policial. Um homem caído no chão tem seu rosto sujo de sangue filmado pela câmera. Ao mencionar o assassinato do guerrilheiro Carlos Marighella, a narração em off afirma que a "guerrilha urbana e isolada do povo foi esfacelada". A luta armada contra a Ditadura não conseguiu derrubar o regime e, neste ponto, o documentário Jango parece indicar que o autoritarismo da Ditadura deixou os opositores do regime sem saída. Como que para reforçar esse sentimento de que não se podia escapar do autoritarismo, o filme sai do contexto brasileiro e apresenta uma breve análise da conjuntura de todo o continente americano no período. O documentário aborda o assassinato de Ernesto "Che" Guevara" em 1967, o golpe de Estado que derrubou Salvador Allende no Chile em 1973, bem como a chamada Operação Condor, uma aliança estabelecida entre os governos das ditaduras existentes na América Latina daquele período e os Estados Unidos para reprimir qualquer tipo de oposição aos regimes ditatoriais da época, valendo-se para isso do uso de assassinatos.

O fato de diversos países estarem sendo governados por ditaduras naquele momento e o fato de os EUA estarem interessados em garantir a sua influência política sobre a América Latina durante a Guerra Fria são apresentados, no documentário, como fatos que indicavam a falta de "saídas seguras" para todos aqueles que se lançassem na luta em prol da democracia e da justiça social. 0 autoritarismo e a violência estavam por toda a parte. Já perto do final do filme, o quadro desenhado pelo documentário é o de que não havia escapatórias para ninguém que se opusesse ao regime ditatorial. A própria narração em off faz questão de inserir João Goulart nesse quadro. Em pleno exílio, segundo a voz over de José Wilker, Jango "sabia que o seu nome constava nessa lista de políticos condenados [pela Operação Condor]". A situação de "sem saída", descrita no final do filme, reforça a condição trágica não só de Goulart naquele contexto, mas de todos aqueles que eventualmente lutassem pela democracia em tempos tão sombrios.

Se Jânio a 24 Quadros termina de uma forma que remete ao final de uma comédia, Jango, 
por sua vez, termina justamente sob a égide da tragédia. Tomando como base mais uma vez os apontamentos de Hayden White, podemos dizer que a tragédia termina de maneira mais sombria do que a comédia, ressaltando a existência de divisões entre os homens ainda mais terríveis do que aquelas existentes no início da narrativa. A tragédia aponta para uma dura verdade: as condições históricas impõem grandes limites às ações humanas (Cf. WHITE, 2008, p. 24-25). Quando o filme Jango termina, o que se tem é a constatação de que a queda de João Goulart arrastou o país para uma Ditadura terrível, da qual era muito difícil escapar e contra a qual ainda era necessário lutar. Não por acaso, o filme de Silvio Tendler termina de maneira melancólica, ressaltando a permanência, no momento de lançamento do filme, do clima de tensão política no país. É nesse sentido que "as lágrimas derramadas em 64" continuavam "justas", como diz o último verso do poema de Fernando Brant citado ao final do documentário de Tendler, quando a tela exibe uma imagem do túmulo de João Goulart.

\title{
Considerações Finais
}

Em meados da última década do século $X X$, o historiador inglês Eric Hobsbawm escreveu as seguintes palavras que, em nossa avaliação, continuam tendo grande pertinência no que diz respeito ao ofício do historiador:

\begin{abstract}
A destruição do passado - ou melhor, dos mecanismos sociais que vinculam nossa experiência pessoal à das gerações passadas - é um dos fenômenos mais característicos e lúgubres do final do século XX. Quase todos os jovens de hoje crescem numa espécie de presente contínuo, sem qualquer relação orgânica com o passado público da época em que vivem. Por isso os historiadores, cujo ofício é lembrar o que os outros esquecem, tornam-se mais importantes que nunca no fim do milênio. (HOBSBAWM, 2013, p. 13)
\end{abstract}

As tentativas de "destruição do passado" se manifestam na realidade brasileira a partir das próprias dificuldades com as quais o nosso país tem lidado com a memória relativa à Ditadura Militar (1964-1985). Este traumático período da História de nosso país vem sendo o objeto de disputa de uma verdadeira "guerra da memória", como bem descreveu João Roberto Martins Filho (2002), na qual, de um lado, estão aqueles que se opõe ao autoritarismo do regime e, do outro, aqueles que defendem a Ditadura em razão de seu suposto papel desempenhado na luta contra o "perigo comunista" que pairava sobre o Brasil durante a Guerra Fria.

A aprovação da Lei de Anistia em 1979, lei que "perdoou" de uma única vez torturados e torturadores da época da Ditadura, foi uma maneira pela qual se tentou silenciar a respeito da violência de Estado cometida durante os anos em que os militares estiveram no poder. ${ }^{12} \mathrm{O}$ desconforto sentido por alguns grupos sociais em relação aos acontecimentos daquela época veio mais uma vez à tona quando das discussões a respeito da Comissão Nacional da Verdade criada pelo governo da presidenta Dilma Roussef para apurar os crimes cometidos por agentes públicos brasileiros entre os anos de 1946 e 1988 (Cf. QUERO, 2010).

Diante disso, uma declaração como a do atual vice-presidente da República Federativa do Bra-

12 Para uma reflexão crítica sobre a Lei de Anistia, ver o trabalho de Renato Lemos (2002). 
sil, Hamilton Mourão, citada no início deste texto, indica a permanência em nossa sociedade de um discurso que visa apagar alguns dos conflitos ocorridos ao longo de nossa História, desconsiderando o caráter autoritário e violento da Ditadura Militar. É aqui que o historiador deve agir para, conforme disse Hobsbawm, fazer "lembrar o que os outros esquecem". A análise que fizemos dos filmes Jânio a 24 Quadros e Jango nas páginas anteriores pretendeu justamente demonstrar como o diálogo entre Cinema Documentário e História do Brasil pode contribuir para que os debates em torno dos temas do autoritarismo e da democracia em nosso país sejam feitos de modo a ressaltar o valor do Estado democrático de direito e a recusar projetos autoritários de poder.

Se há algo no qual os documentários de Luís Alberto Pereira e Silvio Tendler nos fazem pensar é que, por maiores que sejam as limitações e os problemas da democracia, tal forma de governo será sempre melhor do que qualquer Ditadura. Estes dois documentários produzidos na primeira metade dos anos 1980, bem na época em que o Brasil passava pela sua redemocratização, são documentos que nos fazem recordar a importância dos valores democráticos na luta contra qualquer forma de autoritarismo. Esperamos que o nosso breve estudo acerca destes dois filmes possa instigar a produção de mais pesquisas no âmbito da historiografia que visem o enfrentamento das tentativas de se apagar certos episódios do nosso passado, tentativas essas empreendidas por determinados agentes políticos em nossa sociedade.

Lutar contra o esquecimento é uma das principais tarefas do historiador, pois, para recordarmos algumas belas palavras de Paul Ricoeur (2010, p. 129): "Contamos histórias porque, afinal, as vidas humanas precisam e merecem ser contadas. [...] Toda a história do sofrimento clama por vingança e pede narração".

\section{Referências}

BAKHTIN, Mikhail Mikhailovitch. A Cultura Popular na Idade Média e no Renascimento: o contexto de François Rabelais. Tradução de Yara Frateschi Vieira. São Paulo: HUCITEC; Brasília: Ed. UnB, 1987.

BIROLI, Flávia. João Goulart e o golpe de 1964 na imprensa, da transição aos dias atuais: uma análise das relações entre mídia, política e memória. In: CONGRESSO ANUAL DA ASSOCIAÇÃO BRASILEIRA DE PESQUISADORES DE COMUNICAÇÃO E POLÍTICA, 1., 2006, Salvador-BA. Anais[...]. Salvador: [S. n.], 2006. p. 1-25. Disponível em: http://www.compolitica.org/home/wp-content/ uploads/2010/11/Biroli 2006.pdf. Acesso em: 24 ago. 2020.

BITARELLI, Rogério. Os anos loucos. Jornal do Brasil, Rio de Janeiro, 4 ago. 1982. Caderno B, p. 7.

CAPELATO, Maria Helena Rolim. História do Brasil e revisões historiográficas. Anos 90, Porto Alegre, v. 23, n. 43, p. 21-37, jul. 2016. Disponível em: https://dialnet.unirioja.es/descarga/articulo/6719115.pdf. Acesso em: 24 ago. 2020.

CARDOSO, Heloisa Helena Pacheco. Os "anos dourados": memória e hegemonia. ArtCultura, Uberlândia, v. 9, n. 14, p. 169-184, jan./jun. 2007. Disponível em: <http://www.artcultura.inhis.ufu.br/ PDF14/HeloisaCardoso.pdf>. Acesso em: 24 ago. 2020. 
CORRÊA, Villas-Bôas. Jânio para iniciantes ou para quem esqueceu. Jornal do Brasil, Rio de Janeiro, 1 ago. 1982. Caderno B, p. 1.

CORRÊA, Villas-Bôas. Como morreu a democracia. Jornal do Brasil, Rio de Janeiro, 15 fev. 1984. Caderno B, p. 1.

DIAS, Rodrigo Francisco. A recente História política brasileira entre a comédia e a tragédia nos filmes Jânio a 24 Quadros (1981, de Luís Alberto Pereira) e Jango (1984, de Sílvio Tendler). Tese (Doutorado em História Social) - Universidade Federal de Uberlândia, Uberlândia, 2019.

DIAS, Samanta. Sete vezes em que Bolsonaro causou polêmica ao defender a ditadura. Congresso em foco, Brasília, 31 mar. 2019. Disponível em: https://congressoemfoco.uol.com.br/especial/ sete-vezes-em-que-bolsonaro-ganhou-atencao-ao-defender-a-ditadura/. Acesso em: 24 ago. 2020.

HARTOG, François; REVEL, Jacques (Org.). Les usages polítiques du passe. Paris: Enquête, Editions de L'École des Hautes Etudes en Sciences Sociales, 2001.

HOBSBAWM, Eric. Era dos Extremos: o breve século XX: 1914-1991. 2. ed. 50. reimpr. Trad. de Marcos Santarrita. Rev. téc. de Maria Célia Paoli. São Paulo: Cia. das Letras, 2013.

LABAKI, Amir. Sílvio Tendler ampliou discurso histórico do cinema brasileiro. Folha de S. Paulo, São Paulo, 21 jun. 2018. Disponível em: https://www1.folha.uol.com.br/amp/ilustrada/2018/06/ silvio-tendler-ampliou-discurso-historico-do-cinema-brasileiro.shtml. Acesso em: 24 ago. 2020.

LEITE, Paulo Moreira. Acadêmicos da Ironia. Veja, São Paulo, p. 123-125, 10 mar. 1982.

LEMOS, Renato. Anistia e crise política no Brasil pós-1964. Topoi: Revista de História, Rio de Janeiro, v. 3, n. 5, p. 287-313, jul./dez. 2002. Disponível em: http://www.revistatopoi.org/numeros anteriores/topoi05/topoi5a12.pdf. Acesso em: 24 ago. 2020.

MARTINS FILHO, João Roberto. A Guerra da Memória: a ditadura militar nos depoimentos de militantes e militares. Varia História, Belo Horizonte, v. 18, n. 28, p. 178-201, dez. 2002. Disponível em: http://www.variahistoria.org/s/10 Filho-Joao-Roberto-Martins.pdf. Acesso em: 24 ago. 2020.

PAULO, Diego Martins Dória. Os mitos da Brasil Paralelo. Le Monde Diplomatique Brasil, São Paulo, 18 maio 2020. Disponível em: https://diplomatique.org.br/os-mitos-da-brasil-paralelo/. Acesso em: 24 ago. 2020.

QUERO, Caio. Entenda a polêmica sobre a Comissão Nacional da Verdade. BBC Brasil, 13 jan. 2010. Disponível em: https://www.bbc.com/portuguese/noticias/2010/01/100112 comissao qanda cq. Acesso em: 24 ago. 2020.

RICOEUR, Paul. Tempo e Narrativa: a intriga e a narrativa histórica. Tra. de Claudia Berliner. Rev. trad. de Márcia Valéria Martinez de Aguiar. Introd. de Hélio Salles Gentil. São Paulo: Editora WMF Martins Fontes, 2010. v. 1.

SCHILD, Susana. "Jango": a história que começa a ser contada. Jornal do Brasil, Rio de Janeiro, 15 fev. 1984. Caderno B, p. 1.

SCHWARCZ, Lilia Moritz. Sobre o autoritarismo brasileiro. São Paulo: Cia. das Letras, 2019. 
WHITE, Hayden. Meta-História: a imaginação histórica do Século XIX. 2. ed. Trad. de José Laurênio de Melo. São Paulo: EDUSP, 2008. 